\title{
Effect of Initial Configuration on DFT Calculations for Transition Metal Complexes
}

\author{
Nil E. Binbay ${ }^{1 *}$, Veysel Binbay ${ }^{2}$, Murat Aydemir $^{3}$, Feyyaz Durap $^{4}$, Nermin Meriç ${ }^{5}$, Cezmi Kayan $^{6}$, Nevin \\ Arslan $^{7}$ \\ ${ }^{1}$ Department of Electronics, Vocational School, Dicle University, Turkey (ORCID: 0000-0002-2488-0378) \\ 2 Department of Physics, Institute of Natural Science, Dicle University, Turkey (ORCID: 0000-0002-1018-5438) \\ ${ }^{3}$ Department of Chemistry, Faculty of Science, Dicle University, Turkey (ORCID: 0000-0002-4238-5012) \\ ${ }^{4}$ Department of Chemistry, Faculty of Science, Dicle University, Turkey (ORCID: 0000-0899-1948) \\ ${ }^{5}$ Department of Chemistry, Faculty of Science, Dicle University, Turkey (ORCID: 0000-0003-0456-5124) \\ ${ }^{6}$ Department of Chemistry, Faculty of Science, Dicle University, Turkey (ORCID: 0000-0001-5700-8546) \\ ${ }^{7}$ Department of Field Crops, Faculty of Agriculture, Sirnak University, Turkey (ORCID: 0000-0003-0142-9215)
}

(This publication has been presented orally at HORA congress.)

(First received 1 August 2019 and in final form 25 October 2019)

(DOI: $10.31590 /$ ejosat.638072)

ATIF/REFERENCE: Binbay, N. E., Binbay V., Aydemir, M., Durap, F., Meriç. N., Kayan, C. \& Arslan, N. (2019). Effect of Initial Configuration on DFT Calculations for Transition Metal Complexes. European Journal of Science and Technology, (Special Issue), 256-269.

\begin{abstract}
Computational methods, which solves the Schrödinger's equation for molecules, have become an indispensable tool in last decades. And Density Functional Theory is one of the most used, and most effective computational method.

Transition Metal complexes, on the other hand, have been being used extensively in many important applications in many fields, such as chemical catalysts, atomic thin films, and pharmaceutical industry. Applying computational methods to transition metal complexes has become inevitable to understand better, to control and to design these compounds.

As it is known, it is very difficult to handle transition metals computationally, mostly due to near degeneracy in their electronic states. The computational algorithms usually cannot achieve as successive result as they can do for other typical elements, like carbon or nitrogen for instance. Computational methods are needed to be improved for properly deal with transition metal complexes. To find computationally cheaper but still effective methods to deal with these complexes is a major challenge.

Unlike the analogue calculations, computational methods solve all equations iteratively, so there are major differences between these two calculation types. The starting point in state space (the assumed initial conformation of molecule) is could have a stronger effect then the expected, on the flow of the iterative solving algorithm of the computational approach.

Here we present a comparative study for a Ruthenium complex. We have optimised the molecule several times. Each of the optimisations started from different initial molecular conformations. Then we have compared the result in different ways, like calculation times and minimum energy that had reached, to see effect of starting configurations on the calculation.

It is showed that, starting configuration is an important parameter for computational calculations of transition metal complexes, and it is needed to be carefully chosen to improve success of calculations.
\end{abstract}

Keywords: DFT, Ruthenium, Computation.

\section{Geçiş Metalleri İçin Yürütülen DFT Hesaplamalarına Başlangıç Konfigürasyonunun Etkisi}

$\ddot{\mathbf{O} z}$

Moleküller için Schrödinger denklemini çözen hesaplamalı kimya metodları, son yıllarda gözardı edilemez araçlar haline gelmiştir. Density Functional Theory (DFT) de bu metodlar arasında en etkili olup, en çok kullanılanlardan biri olagelmiştir. 
Geçiş metalleri, öte yandan, kimyasal katalizörler, atomic ince film üretimi, ilaç endüstrisi gibi sayılabilecek pek çok alanda önemli uygulamalarda artan bir yoğunlukta kullanılagelmiştir. Bu çerçevede hesaplamalı kimya araçlarının geçiş metalleri için uygulanması, bu bileşikleri deha iyi anlamak, control etmek ve tasarlamak için kaçınılmaz hale gelmiştir.

Bilindiği üzere geçiş metallerini hesaplamalı araçlarla ele almak, sahip oldukları dejenere kuantum durumları nedeniyle, oldukça zordur. Bu nedenle hesaplamalı kuantum kimya algoritmaları, diğer elementlerin bileşikleri için elde ettikleri başarıyı, geçiş metalleri için de en azından aynı kolaylıkla elde edemezler.

Bu nedenle hesaplama araçlarının, geçiş metallerini daha kolay ele alabilecek şekilde geliştirilmesine ihtiyaç duyulmaktadır. Geçiş metallerini ele almak üzere, daha az hesaplama kaynağı gerektiren ama öte yandan daha efektif yöntemler bulmak, günümüz araştırmacılarının yoğun olarak uğraştı̆̆ konulardan biridir.

Analog çözümlerden farklı olarak, nümerik yaklaşımlar denklemleri iteratif yollarla çözerler, dolayısıyla bu iki çözüm yöntemi arasında temel farklılıklar vardır. Durum uzayındaki başlangıç noktanız, nümerik yaklaşımınızdaki iteratif bir çözüm sürecinin akışı üzerinde beklentinin üzerinde, dramatik şekilde etkili olabilir.

Biz burada, bir geçiş metali olan Ruthenium içeren bir bileşik için karşılaştırmalı bir çalışma yürüttük. Söz konusu molekülü, her seferinde farklı bir başlangıç konfigürasyonu kullanarak defalarca optimize ettik. Sonrasında, farklı başlangıç noktalarının etkilerin görmek üzere, sonuçları, hesaplama zamanlarındaki değişim, varılan minimum enerji konfigürasyonlarındaki farklılık gibi değiş̧ik açılardan kıyasladık.

Sonuçta başlangıç konfigürasyonunun, geçiş metali içeren bileşikler için yürütülen nümerik hesaplamalarda önemli bir parameter olduğunu ve hesaplamaların başarısını arttırmak için dikkatli seçilmesi gerektiğini ortaya koyduk.

Anahtar Kelimeler: DFT, Rutenyum, Hesaplama.

\section{Introduction}

Calculation capacities of computers have been significantly improved over last decades. Due to this improvement, computational tools have become applicable to the many branch of chemistry. Computational chemists have been able to deal with large molecules, like proteins, within reasonable calculation times.(Elstner, Frauenheim, \& Suhai, 2003) And they have also been able to deal with harder problems, like searching transition states, handling transition metal complexes, etc...(Siegbahn, 2006) Although computational methods have greatly been improved, it is a still going on process. Modifying the existing methods and contributing them to get more effective ones in any way is still a major challenge.(Witte, Neaton, \& Head-Gordon, 2017)

Transition metal complexes, have always been hard ones to be handled computationally, due to their existing near degenerate electronic states, and they still are.(Pinter, Chankisjijev, Geerlings, Harvey, \& De Proft, 2018) (Zhang et al., 2016) Optimisation algorithms, for instance, frequently failed to being converged for transition metal complexes.

The most fundamental way to understand chemical reactions and behaviour of atoms and molecules, on the other hand, is to imagine their interactions by the terms of the moving objects in a multi-dimensional hyperspace which called as Potential Energy Surface (PES). (Car \& Parrinello, 1985; Kim, Park, Son, Sim, \& Burke, 2015)This holds true for both of the analytical and numerical approaches. Every configuration of a molecule, is represented as a single point in state space, and also in PES. A chemical reaction, is represented with combination of the starting point, the pathway and the destination point in multi-dimensional state space, and also PES. All of the chemistry, computational or not, can be considered as to analyse equation of motions of some quantum objects moving in PES. Computationally, optimising process a molecule to find its optimum configuration, is actually is just a mathematical algorithm to find a deepest point of a hole in a multi-dimensional hypersurface (PES). Usually the starting point is an important parameter which effect directly to the pathway and to the destination directly.

Computational methods, solve the Schrödinger's equation, to define PES and also to analyse reaction pathways, which is hard to be solved in general. So to find reasonable starting points, some predefined algorithms, called as force fields, is used, with less computational effort than Schrödinger's equation needs. Universal Force Field (UFF) is one of the most useful and popular force field.(Rappe, Casewit, Colwell, Goddard, \& Skiff, 1992)

If you deal a problem with a starting point, a pathway and a destination, then you might have thought as this, how the starting point close to the destination, then it is that much shorter the pathway and so iterative computation is easier, hence finishes faster. But it is actually not the case always. Sometimes, it is not as advantageous to start closer to the destination point, in PES.

The aim of this work is to analyse the effect of the starting point on to the pathway toward to the destination point, in detail, calculation times and the final energies of optimised configurations, for transition metal complexes.

\section{Material and Method}

A typical Ruthenium complex, which have half sandwich piano stool geometry with a benzene ring and chlorines, selected as the object molecule for comparison. The molecule was optimised by using a general ab initio quantum chemistry package GAMESS (the General Atomic and Molecular Electronic Structure System).(Dykstra, Frenking, \& Kim, 2011; Schmidt et al., 1993) The DFT (Density Functional Theory)(Hohenberg \& Kohn, 1964) was employed for ab-initio calculations of the molecule. The hybrid Becke, threeparameter, Lee-Yang-Parr, using coulomb attenuating method (CAM-B3LYP) (Yanai, Tew, \& Handy, 2004) was used as exchange 
correlation functional for DFT calculations. The basis set that used for calculation was the SBKJ (Stevens, Bash, Krauss, Jasien) valance with ECP (Effective Core Potential)(Stevens, Krauss, Basch, \& Jasien, 1992). The Ruthenium molecule was optimized several times, by using the same hardware, the same software, the exact same parameter set, except that the different starting points. Ruthenium molecule was optimised eight times, the results have compared and reported.

\section{Results and Discussion}

We have used the UFF first, to find a reasonable starting point, just as usually done in a typical computation. The starting point for this calculation, which was obtained by UFF, have given in Figure-1. The initial energy of the complex was $-198,8385$ au for this configuration.
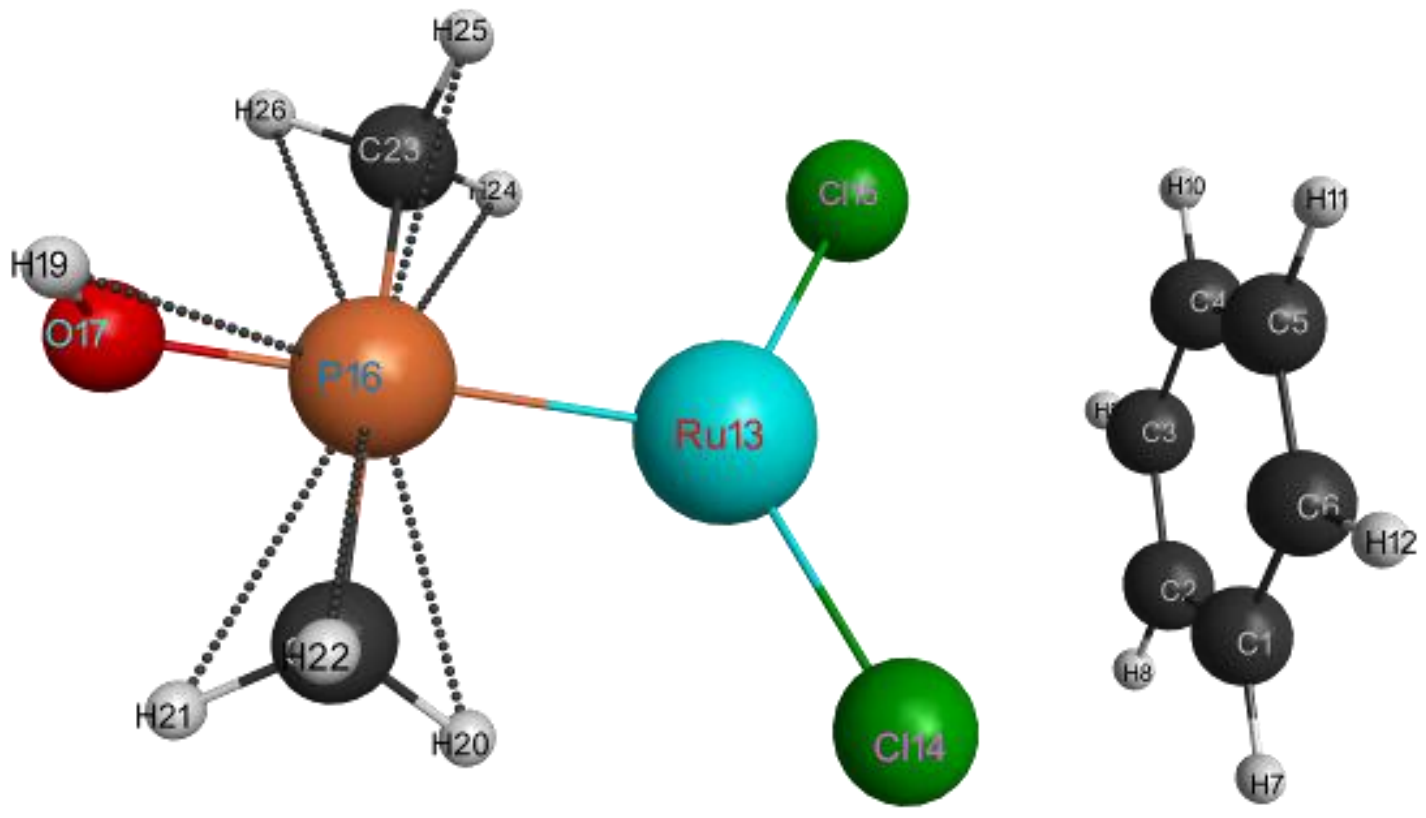

Figure 1 The initial configuration of the complex, after UFF.

Then, we had started the optimisation with GAMESS package. Optimisation had finished after 167 iteration steps and 572.3 minutes. The optimised energy of the complex was -199,1471 au. The final optimized structure of the complex and also Energy Diagram of the optimisation process, which is actually the 2 dimensional projection of the PES, have given in Figure- 2 .
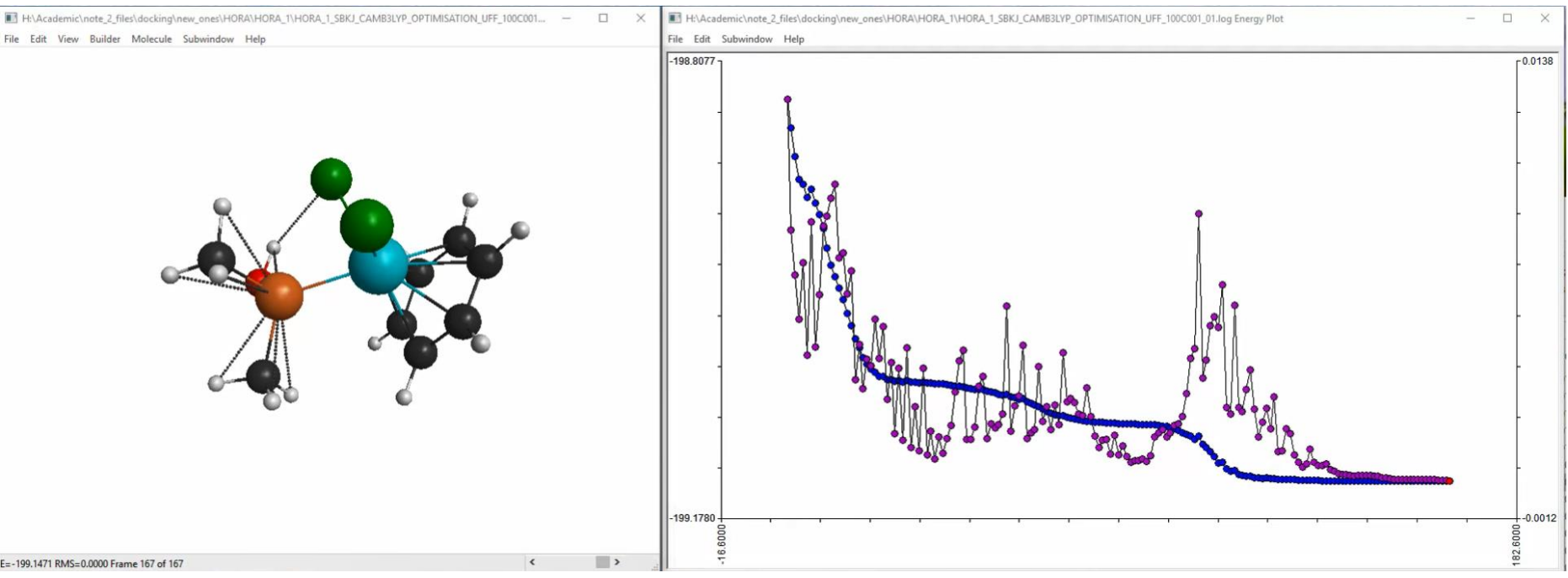

Figure 2 The optimised final structure, and the Energy Diagram of the complex. 
Then, to see the effect of different starting point, we take the first initial configuration, and then intentionally moved the H7 atom, but left other atoms at exact same position. Hence, we had changed the initial configuration, which obtained by UFF, by manipulating $\mathrm{H} 7$ atom, that belongs to the benzene ring. The manipulated initial configuration of the complex has given in Figure-3. The initial energy of the complex was $-198,5809$ au for this $\mathrm{H} 7$ manipulated initial configuration.
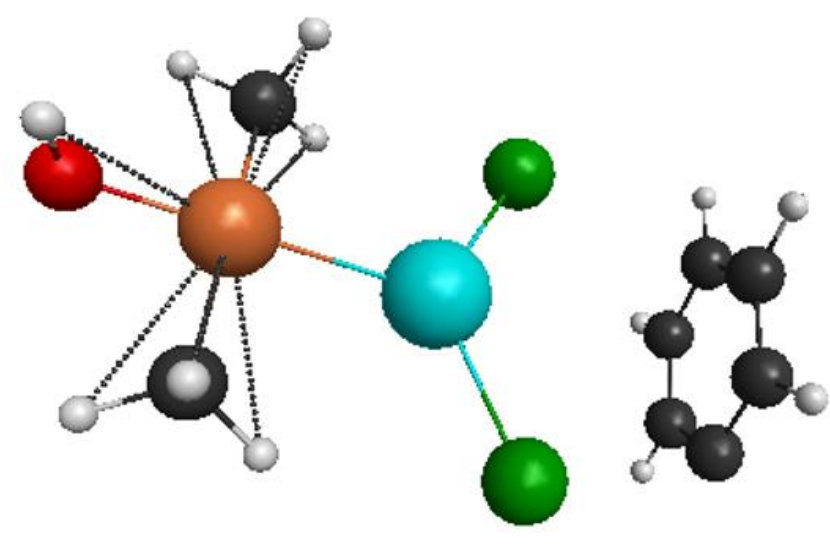

Figure 3 The second initial configuration of the complex, which H7 manipulated.

Then, we had repeated the optimisation process, with GAMESS package, with exact same parameters, and H7 manipulated initial configuration. Optimisation had finished after 145 iteration steps and 422,7 minutes. The optimised final energy of the H7 manipulated complex was $-199,1472$ au. The final optimized structure of the complex and also Energy Diagram of the optimisation process, which belong to the $\mathrm{H} 7$ manipulated initial configuration, have given in Figure-4.

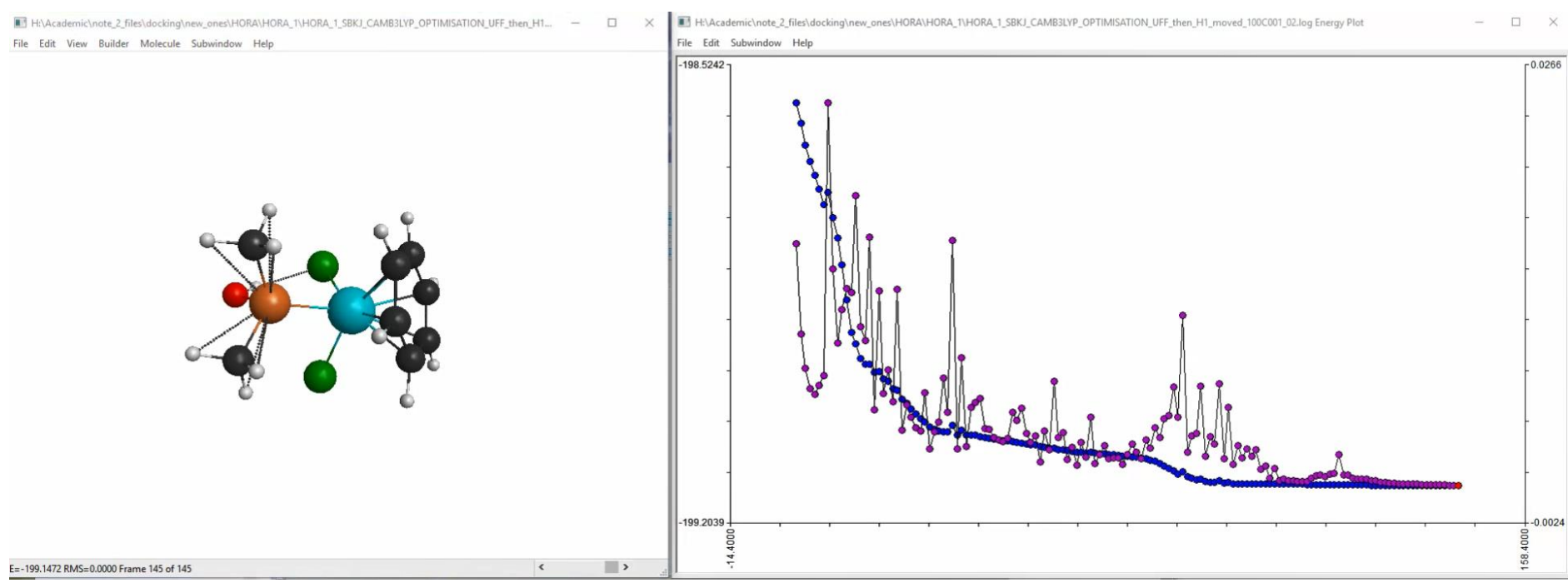

Figure 4 The optimised final structure, and the Energy Diagram of the H7 manipulated initial configuration of complex.

Then, to see the effect of different starting point, again we take the first initial configuration, and then intentionally moved the H9 atom this time, but left other atoms at exact same position. Hence, we had changed the initial configuration, which obtained by UFF, by manipulating $\mathrm{H} 9$ atom, that belongs to the benzene ring. The manipulated initial configuration of the complex has given in Figure-5. The initial energy of the complex was $-198,5723$ au for this H9 manipulated initial configuration. 


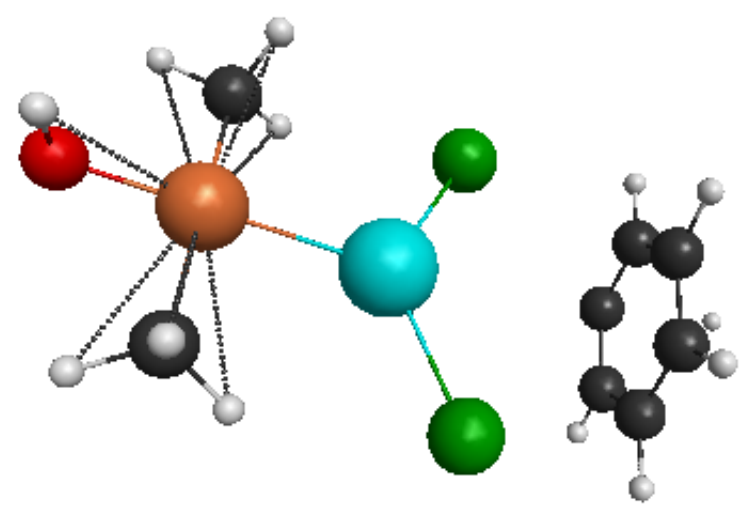

Figure 5 The third initial configuration of the complex, which $H 9$ manipulated.

Then, we had repeated the optimisation process, with GAMESS package, with exact same parameters, and H9 manipulated initial configuration. Optimisation had finished after 142 iteration steps and 393,4 minutes. The optimised final energy of the H9 manipulated complex was $-199,1472$ au. The final optimized structure of the complex and also Energy Diagram of the optimisation process, which belong to the H9 manipulated initial configuration, have given in Figure-6.

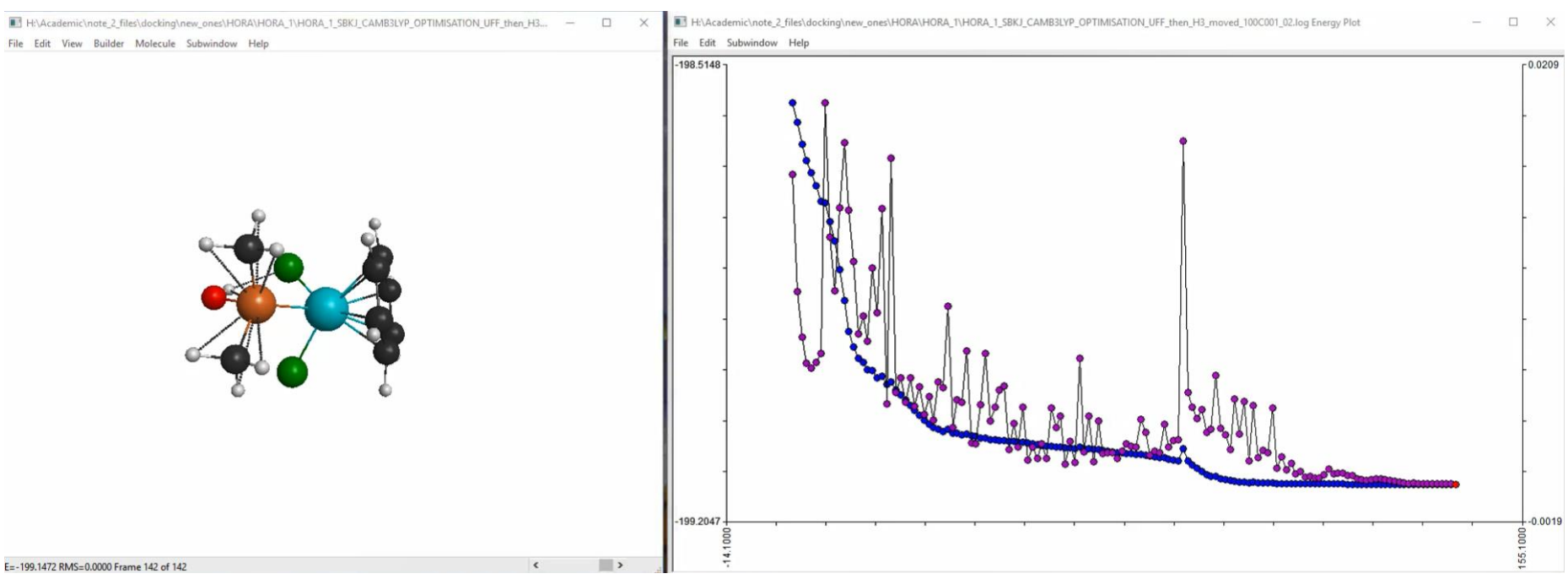

Figure 6 The optimised final structure, and the Energy Diagram of the $H 9$ manipulated initial configuration of complex.

Then, to see the effect of different starting point, again we take the first initial configuration, and then intentionally moved the H19 atom this time, but left other atoms at exact same position. Hence, we had changed the initial configuration, which obtained by UFF, by manipulating H19 atom, that belongs to the oxygen atom. The manipulated initial configuration of the complex has given in Figure_7. The initial energy of the complex was $-198,7093$ au for this H19 manipulated initial configuration. 


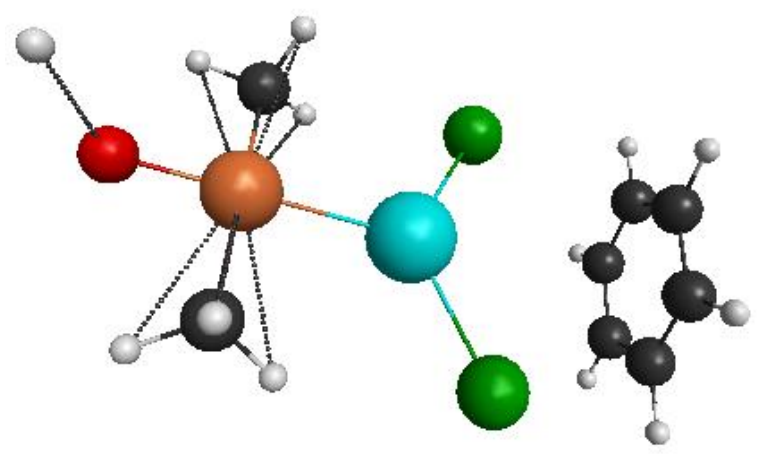

Figure 7 The fourth initial configuration of the complex, which H19 manipulated.

Then, we had repeated the optimisation process, with GAMESS package, with exact same parameters, and H19 manipulated initial configuration. Optimisation had finished after 130 iteration steps and 370,2 minutes. The optimised final energy of the H19 manipulated complex was $-199,1472$ au. The final optimized structure of the complex and also Energy Diagram of the optimisation process, which belong to the H19 manipulated initial configuration, have given in Figure-8.

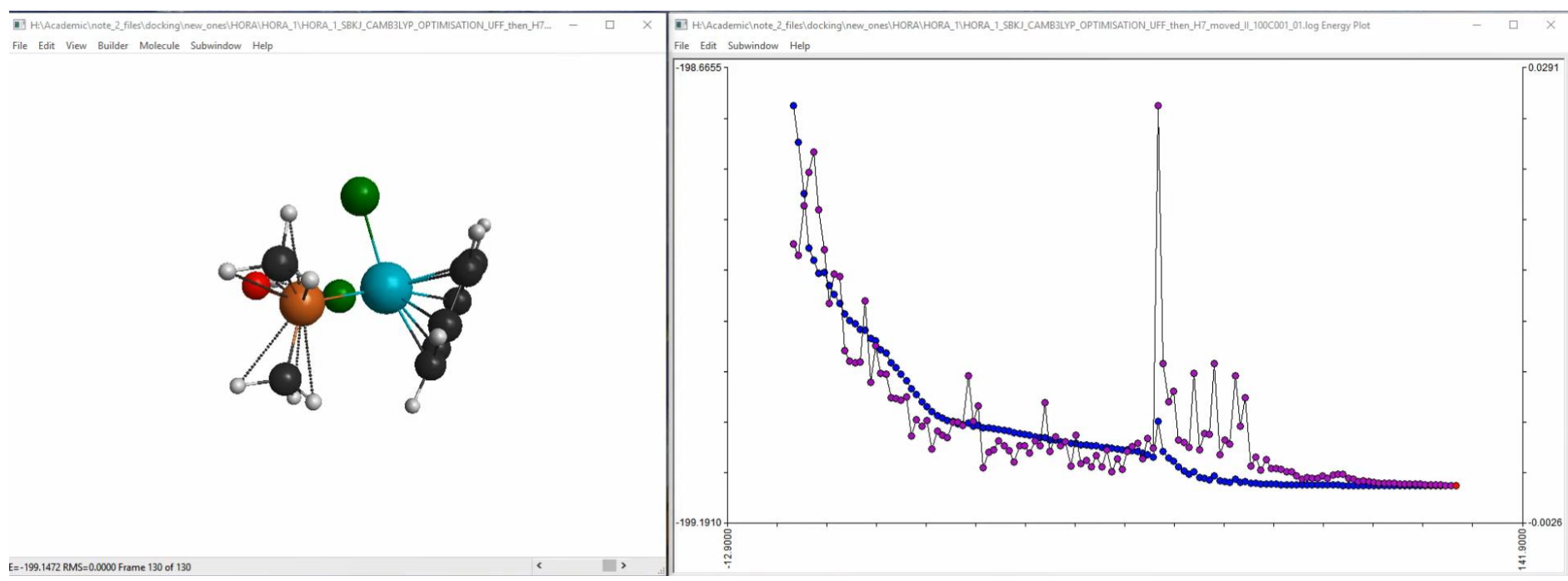

Figure 8 The optimised final structure, and the Energy Diagram of the $H 19$ manipulated initial configuration of complex.

Then, to see the effect of different starting point, again we take the first initial configuration, and then intentionally moved the Ru atom this time, but left other atoms at exact same position. Hence, we had changed the initial configuration, which obtained by UFF, by manipulating $\mathrm{Ru}$ atom. The manipulated initial configuration of the complex has given in Figure-9. The initial energy of the complex was $-198,8603$ au for this Ru manipulated initial configuration. 

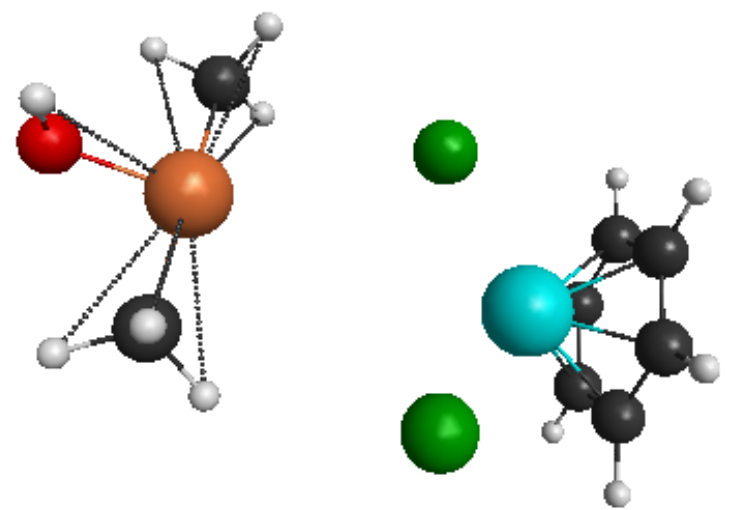

Figure 9 The fifth initial configuration of the complex, which Ru manipulated.

Then, we had repeated the optimisation process, with GAMESS package, with exact same parameters, and Ru manipulated initial configuration. Optimisation had finished after 65 iteration steps and 172,2 minutes. The optimised final energy of the Ru manipulated complex was -199,0839 au. The final optimized structure of the complex and also Energy Diagram of the optimisation process, which belong to the Ru manipulated initial configuration, have given in Figure-10.

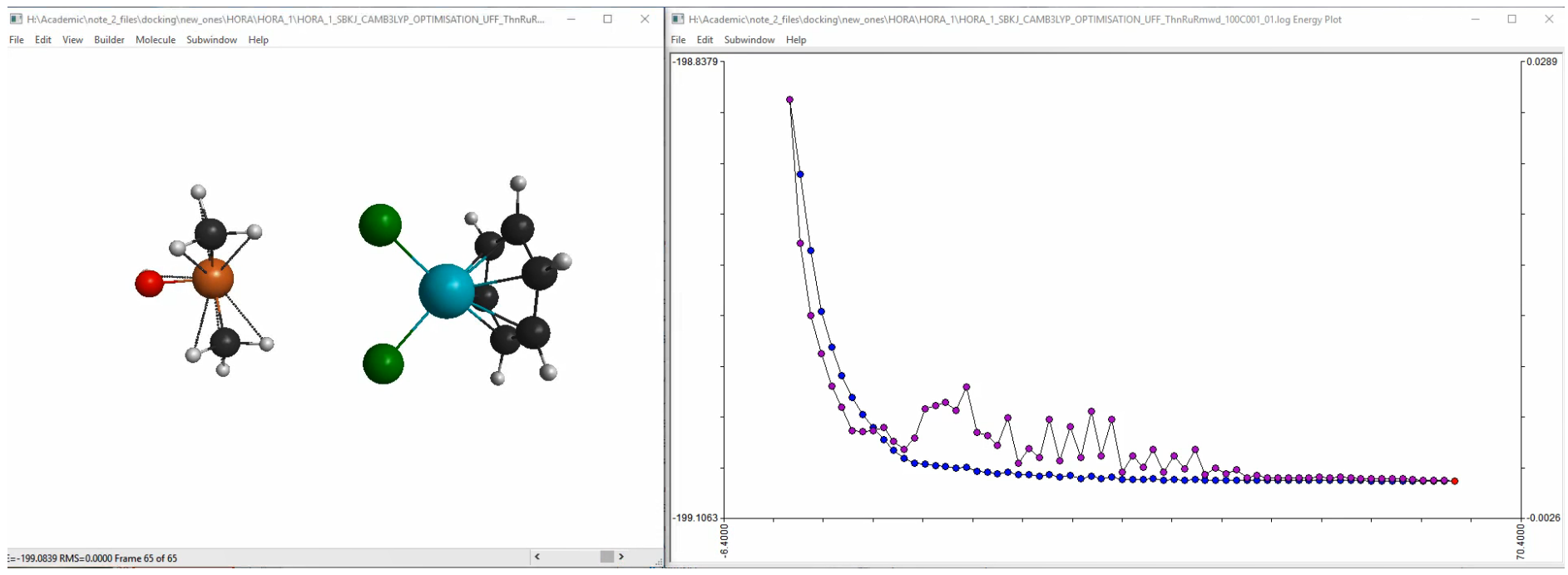

Figure 10 The optimised final structure, and the Energy Diagram of the Ru manipulated initial configuration of complex.

Then, to see the effect of different starting point, again we take the first initial configuration, and then intentionally moved the Cl14 atom this time, but left other atoms at exact same position. Hence, we had changed the initial configuration, which obtained by UFF, by manipulating Cl14 atom. The manipulated initial configuration of the complex has given in Figure-11. The initial energy of the complex was $-198,7356$ au for this Cl14 manipulated initial configuration. 

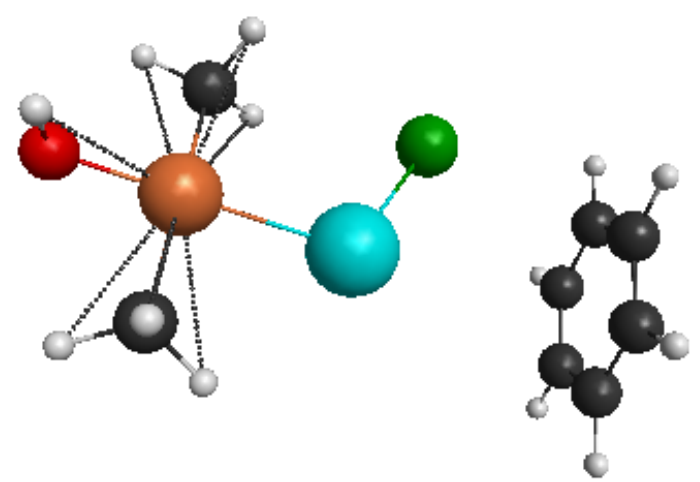

Figure 11 The sixth initial configuration of the complex, which Cl14 manipulated.

Then, we had repeated the optimisation process, with GAMESS package, with exact same parameters, and Cl14 manipulated initial configuration. Optimisation had finished after 137 iteration steps and 434,6 minutes. The optimised final energy of the Cl14 manipulated complex was $-199,1472$ au. The final optimized structure of the complex and also Energy Diagram of the optimisation process, which belong to the Cl14 manipulated initial configuration, have given in Figure-12.

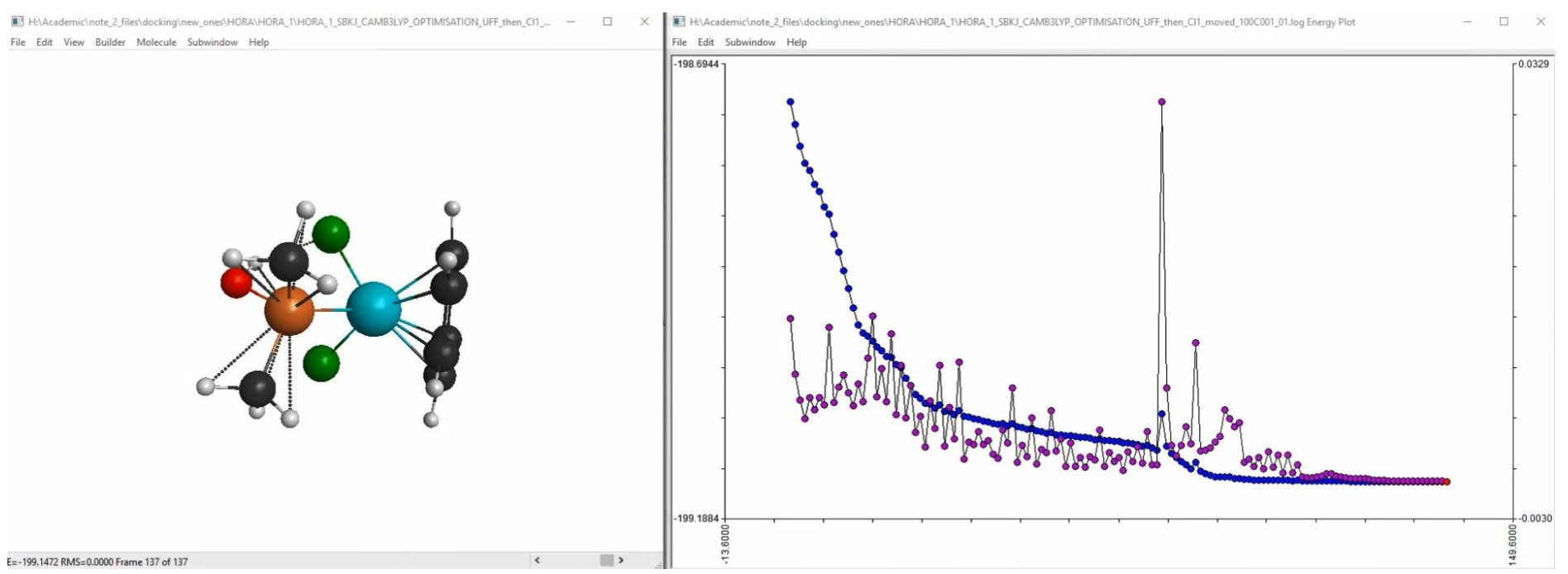

Figure 12 The optimised final structure, and the Energy Diagram of the Cl14 manipulated initial configuration of complex.

Then, to see the effect of different starting point, again we take the first initial configuration, and then intentionally moved more than one atoms this time, especially chlorines and Ru together. Hence, we had changed the initial configuration, which obtained by UFF, by manipulating more than one atom. The manipulated initial configuration of the complex has given in Figure-13. The initial energy of the complex was $-198,4945$ au for this more than one atoms manipulated initial configuration. 


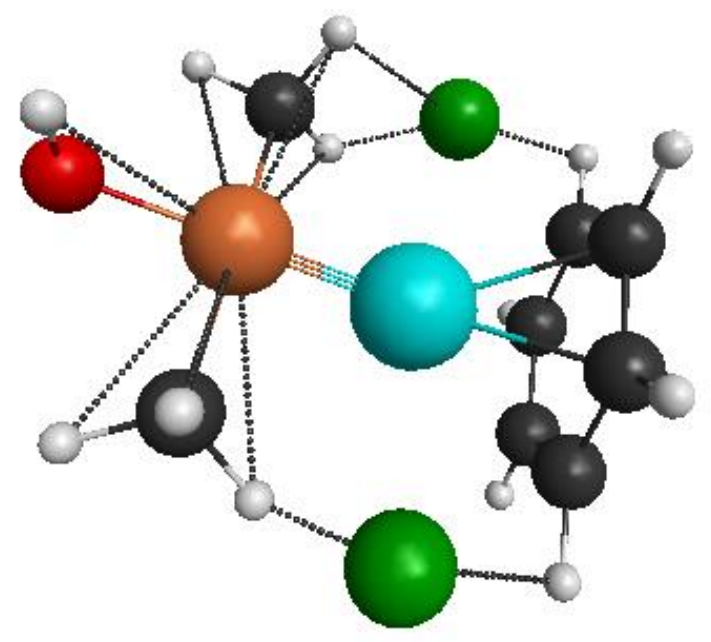

Figure 13 The seventh initial configuration of the complex, which more than one atoms manipulated.

Then, we had repeated the optimisation process, with GAMESS package, with exact same parameters, and more than one atoms manipulated initial configuration. Optimisation had finished after 198 iteration steps and 696,9 minutes. The optimised final energy of the more than one atoms manipulated complex was -199,0905 au. The final optimized structure of the complex and also Energy Diagram of the optimisation process, which belong to the more than one atoms manipulated initial configuration, have given in Figure-14.

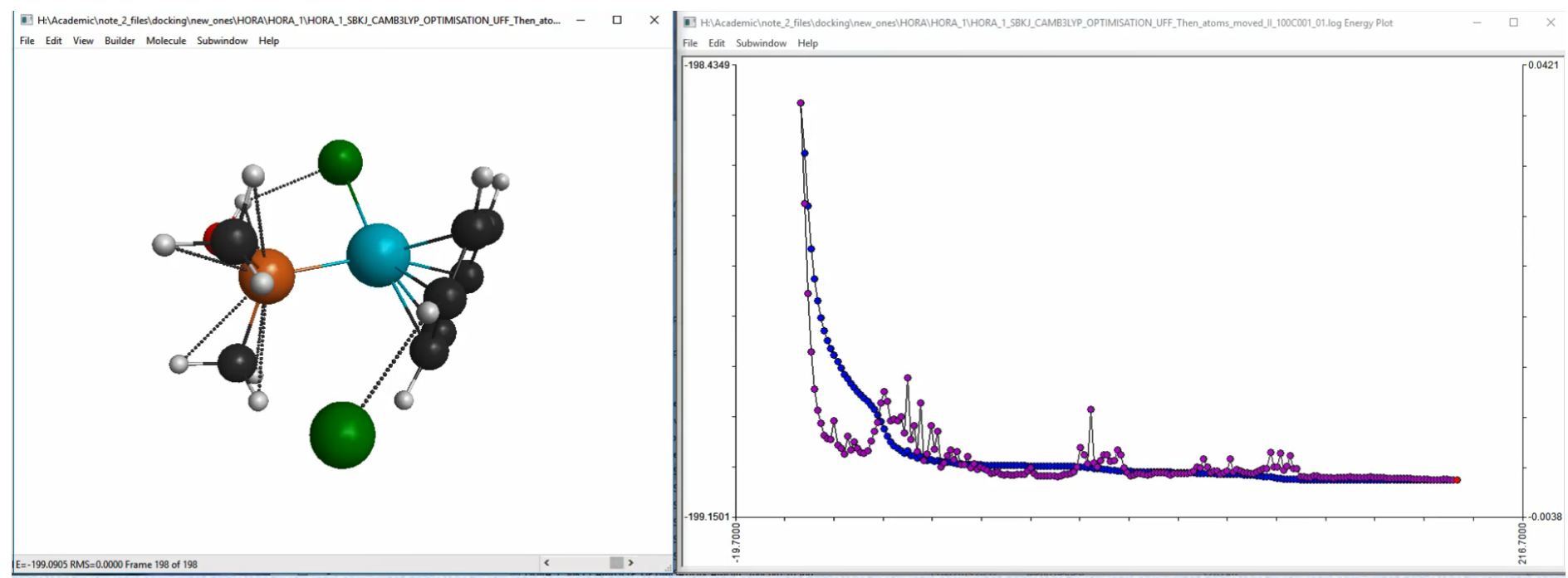

Figure 14 The optimised final structure, and the Energy Diagram of the more than one atoms manipulated initial configuration of complex.

Then, to see the effect of different starting point, again we take the first initial configuration, and then intentionally moved every atoms this time, so we had an amorphous initial configuration this time. The amorphous initial configuration of the complex has given in Figure-15. The initial energy of the complex was $-197,8113$ au for this amorphous initial configuration. 


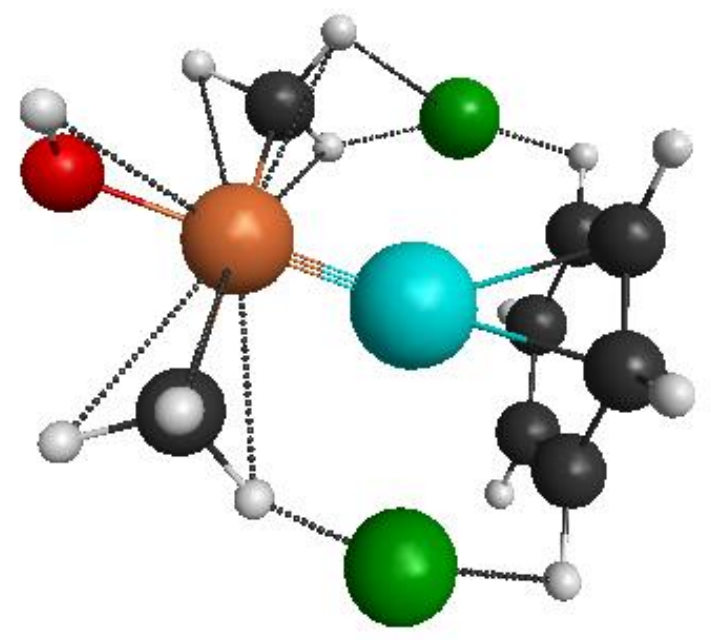

Figure 15 The eighth initial configuration of the complex, which is amorphous configuration.

Then, we had repeated the optimisation process, with GAMESS package, with exact same parameters, and amorphous configuration. Optimisation had finished after 113 iteration steps and 392,7 minutes. The optimised final energy of amorph initial configuration was $-199,1469$ au. The final optimized structure of the complex and also Energy Diagram of the optimisation process, which belong to the amorphous initial configuration, have given in Figure-16.

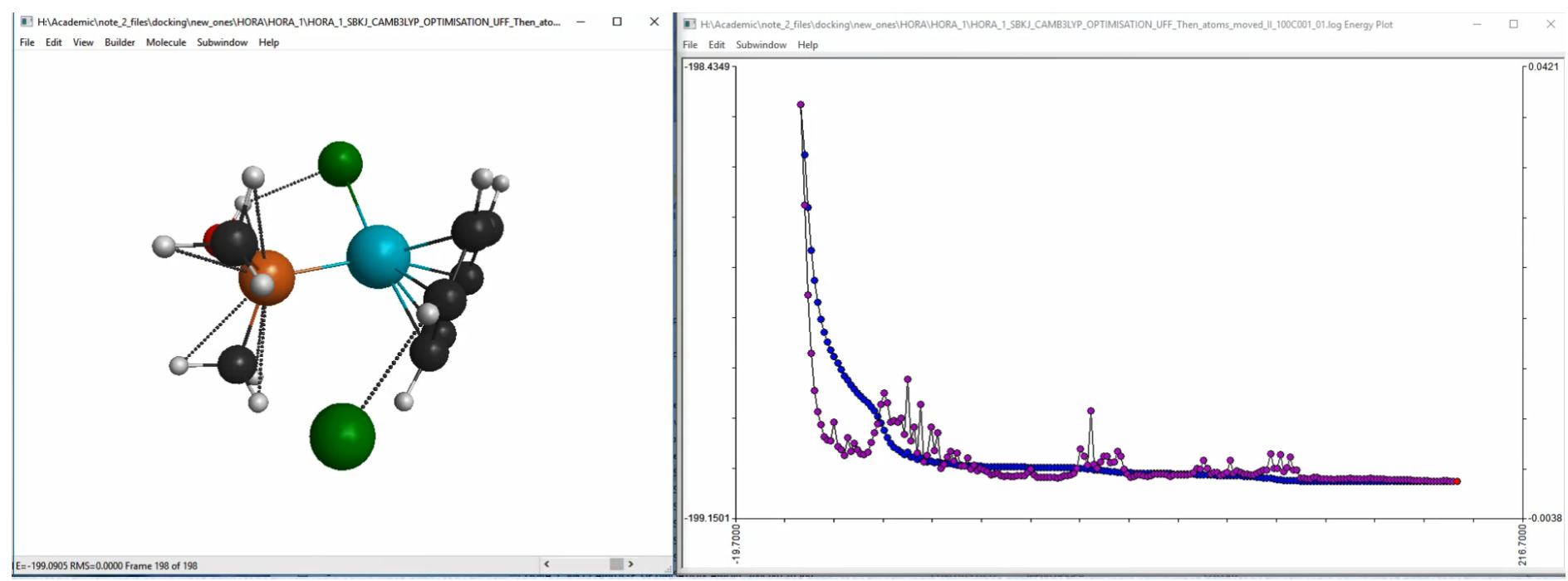

Figure 16 The optimised final structure, and the Energy Diagram of the amorphous initial configuration of complex.

For easier comparison, all of the initial configurations of complex have given in Figure-17 altogether, all of the final optimized configurations of complex have given in Figure-18, and all of the Energy Diagrams of the optimisation processes of complex have given in Figure-19. The calculation times, number of iterations, initial and final energies of complex have given in Table-1 also. 
Avrupa Bilim ve Teknoloji Dergisi

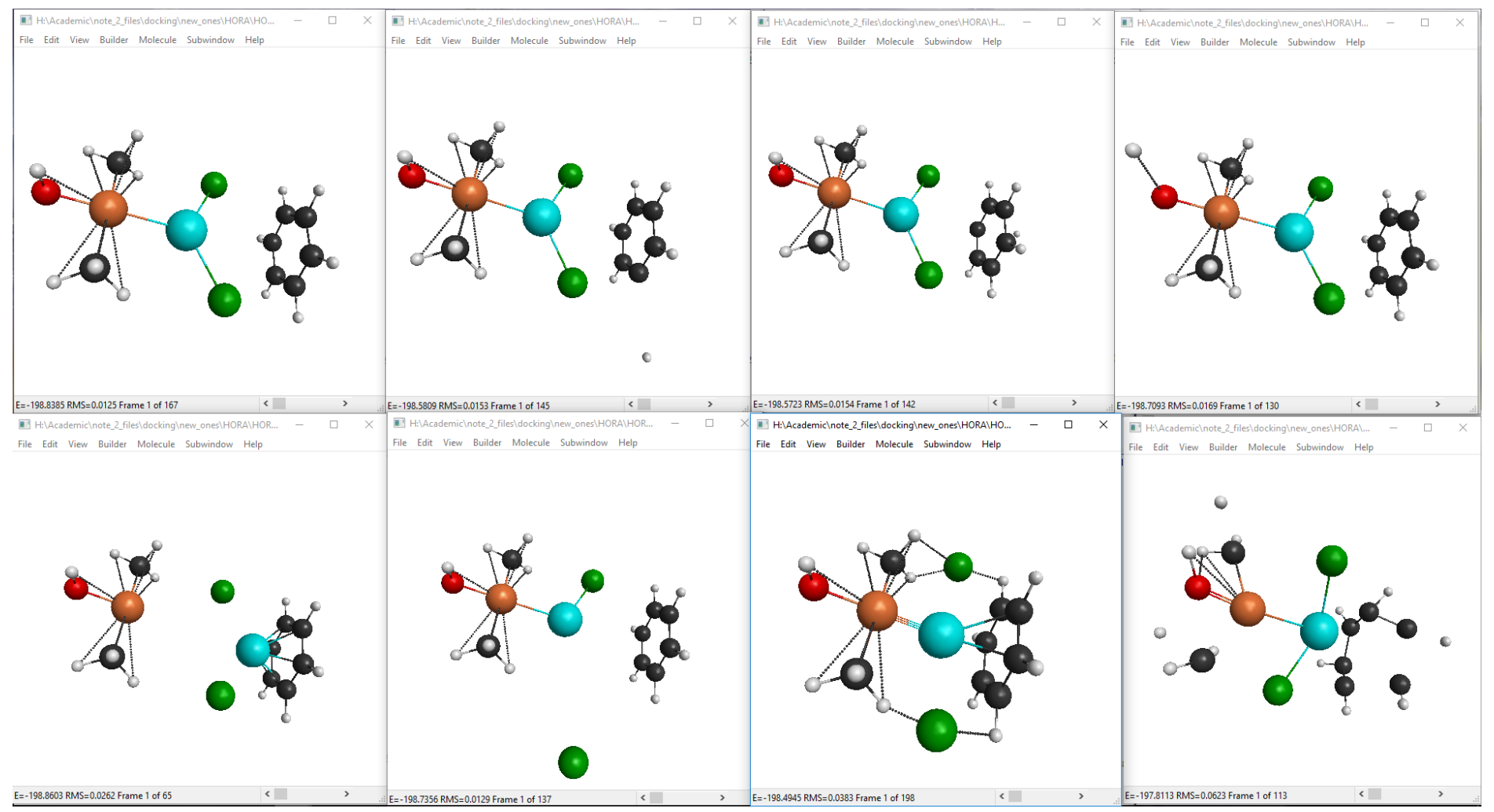

Figure 17 All of the initial configurations of complex.

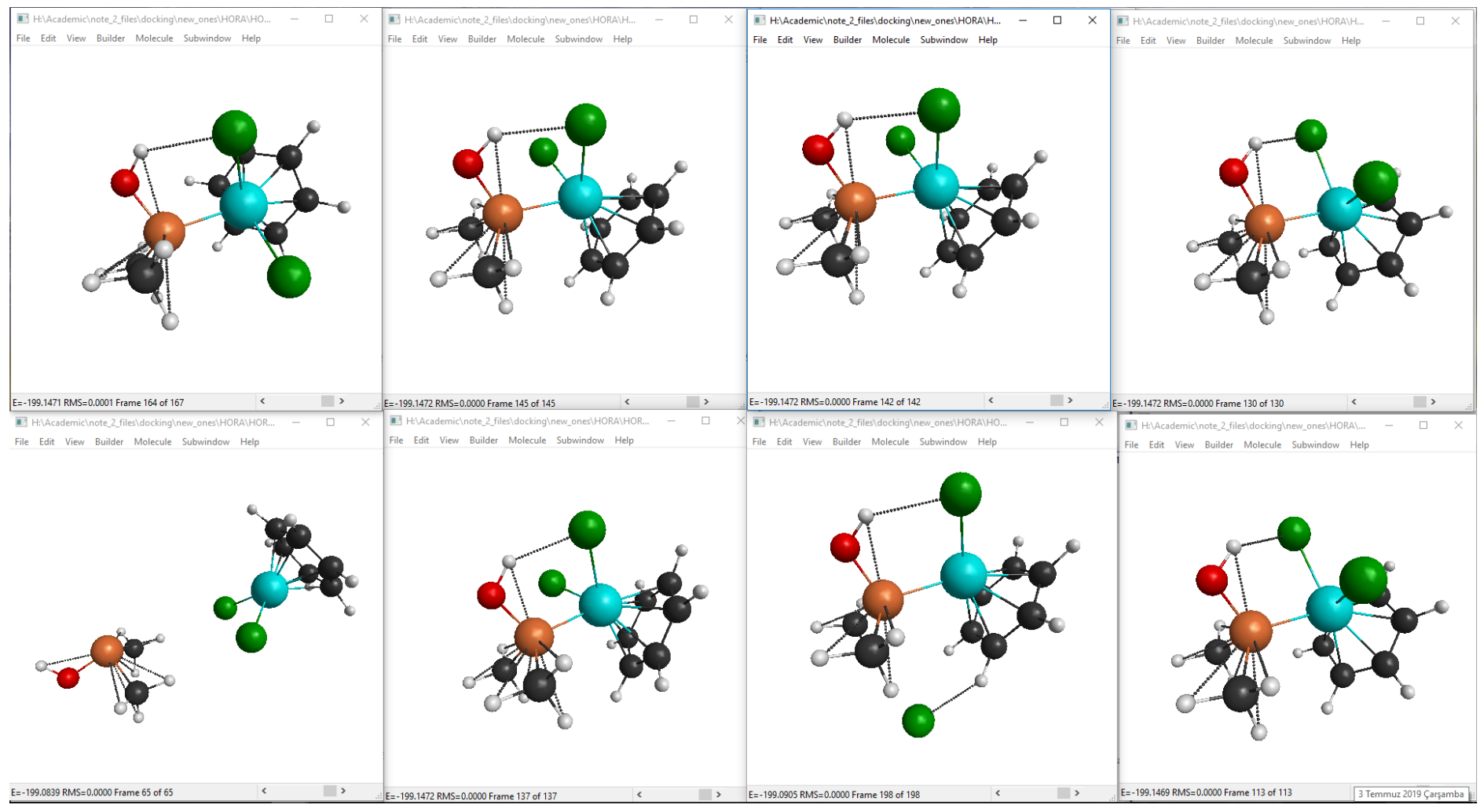

Figure 18 All of the final optimized configurations of complex. 


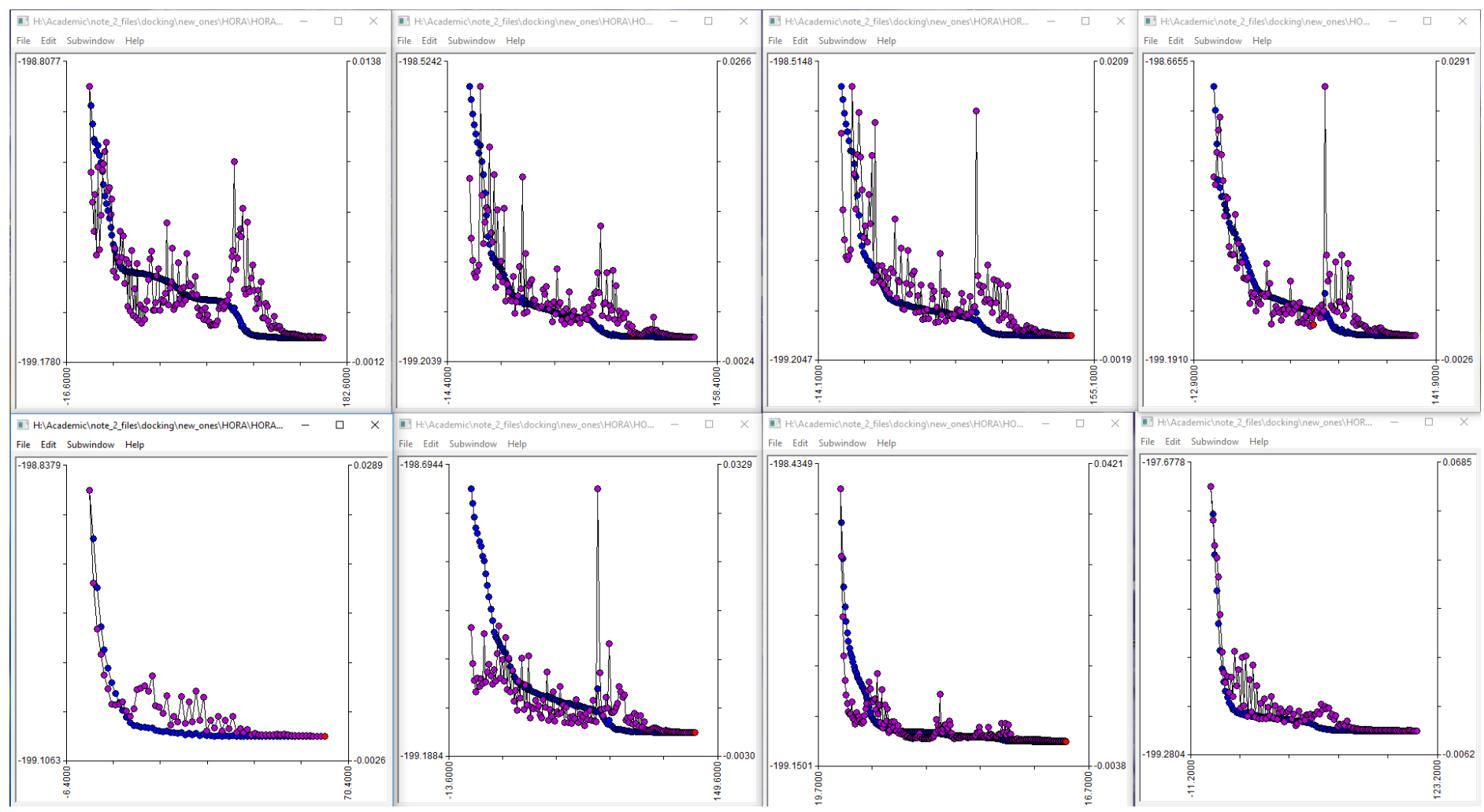

Figure 19 All of the Energy Diagrams of the optimisation processes of complex.

\begin{tabular}{|c|c|c|c|c|c|c|c|}
\hline Initial configurations & $\begin{array}{c}\text { Number of } \\
\text { iterations }\end{array}$ & $\begin{array}{l}\text { Calculation } \\
\text { time (min) }\end{array}$ & $\begin{array}{c}\text { calculation } \\
\text { time per } \\
\text { iteration } \\
\text { (min) }\end{array}$ & $\begin{array}{c}\text { Initial } \\
\text { energy } \\
\text { (au) }\end{array}$ & $\begin{array}{c}\text { Final } \\
\text { energy } \\
\text { (au) }\end{array}$ & $\begin{array}{c}\text { Energy } \\
\text { Distance from } \\
\text { final position } \\
(\mathrm{au})\end{array}$ & $\begin{array}{c}\text { Energy } \\
\text { distance from } \\
\text { min. final } \\
\text { position } \\
\text { (au) }\end{array}$ \\
\hline UFF & 167 & 572,3 & 3,4 & $-198,8385$ & $-199,1471$ & 0,3086 & 0,0001 \\
\hline UFF then $\mathrm{H} 7$ moved & 145 & 422,7 & 2,9 & $-198,5809$ & $-199,1472$ & 0,5663 & 0 \\
\hline UFF then H9 moved & 142 & 393,4 & 2,8 & $-198,5723$ & $-199,1472$ & 0,5749 & 0 \\
\hline UFF then H19 moved & 130 & 370,2 & 2,8 & $-198,7093$ & $-199,1472$ & 0,4379 & 0 \\
\hline UFF then Ru moved & 65 & 172,2 & 2,6 & $-198,8603$ & $-199,0839$ & 0,2236 & $\mathbf{0 , 0 6 3 3}$ \\
\hline UFF then Cl14 moved & 137 & 434,6 & 3,2 & $-198,7356$ & $-199,1472$ & 0,4116 & 0 \\
\hline $\begin{array}{l}\text { UFF then many atoms } \\
\text { moved }\end{array}$ & 198 & 696,9 & 3,5 & $-198,4945$ & $-199,0905$ & 0,596 & 0,0567 \\
\hline Amorphous & 113 & 392,7 & 3,5 & $-197,8113$ & $-199,1469$ & 1,3356 & 0,0003 \\
\hline
\end{tabular}

Table-1 The calculation times, number of iterations, initial and final energies of complex.

All the obtained results have summarized in Graphic-1. 


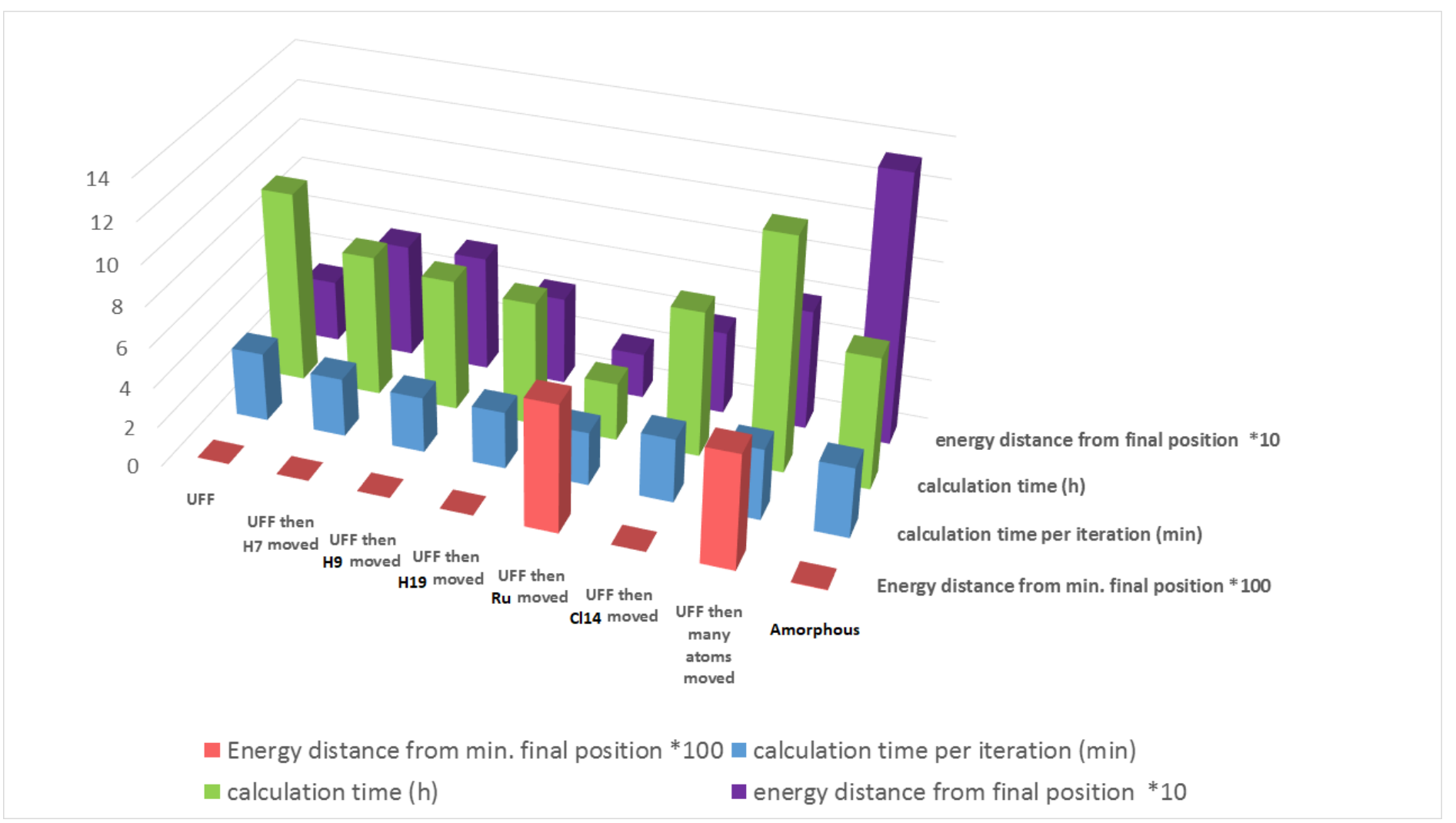

Graphic-1 Comparison graphic of all obtained results. To equalise the scales, some of the data have multiplied by 10 or 100.

As it is seen in Graphic-1, and also in Table-1, moving the starting point away from the final destination, doesn't increases calculation time, as it would be expected wrongly. On the contrary, moving the initial configuration away from destination, actually can decrease the calculation time, as it is seen in $\mathrm{H} 7, \mathrm{H} 9$ and $\mathrm{H} 19$ cases for instance. The conventional UFF initial point has the lower energy $(-198,8355 \mathrm{au})$ than the $\mathrm{H} 7$ manipulated initial configuration $(-198,5809)$, so UFF case is actually closer to the destination point energy $(-199,1471 \mathrm{au})$. But $\mathrm{H7}$ modified case has less iteration steps (145) than the UFF case (167); it also has lower calculation time (422,7 $\mathrm{min}$ ) than the UFF case (572,3 $\mathrm{min})$. Hence, manipulating a non-critical atom, like one of the Hydrogen which belongs to the benzene ring, reduced the computational cost, although the manipulation process moves the initial point away from the destination on the PES.

But on the other hand, starting configuration can be more important than effecting on calculation time or number of iteration steps. As it is seen the case of Ru manipulation, a small difference of initial position of a critical atom, could radically change the reaction pathway, just as in our case, it could have ended by the totally different destination point.

\section{Conclusions and Recommendations}

Finally, it is concluded that; manipulating initial configurations intentionally, could have increase effectiveness of your computations by lower computational times, reduced iteration steps, for transition metal complexes. But it might be dangerous also, to manipulate critical atoms like transition metals itself. This may end up all with all the computation to go to a totally different direction.

As it is seen, in computational approaches, starting as close as possible to the targeted minim points in PES, actually is not as advantageous as it is expected. Hence, it is recommended that, start with some cheap algorithm (like UFF) first, as usual, then move a non-critical atom (such as a Hydrogen which belongs to the an arene ring) just a little amount, and then start your optimisation process.

This work, have put forward the importance of starting configuration of transition metal complexes on PES. To reach more precise rules and finally novel optimised techniques, which findings of this work implies their existence, it is needed to extended studies to investigate effect of starting configurations on computational processes.

\section{References}

Car, R., \& Parrinello, M. (1985). Unified Approach for Molecular Dynamics and Density-Functional Theory. Physical Review Letters, 55(22), 2471-2474. https://doi.org/10.1103/PhysRevLett.55.2471

Dykstra, C., Frenking, G., \& Kim, K. (2011). Theory and Applications of Computational Chemistry: The First Forty Years. Retrieved from http://qut.eblib.com.au/patron/FullRecord.aspx?p=269993

Elstner, M., Frauenheim, T., \& Suhai, S. (2003). An approximate DFT method for QM/MM simulations of biological structures and processes. Journal of Molecular Structure: THEOCHEM, 632(1-3), 29-41. https://doi.org/10.1016/S0166-1280(03)00286-0 
Hohenberg, P., \& Kohn, W. (1964). Inhomogeneous Electron Gas. Physical Review, 136(3B), B864-B871. https://doi.org/10.1103/PhysRev.136.B864

Kim, M.-C., Park, H., Son, S., Sim, E., \& Burke, K. (2015). Improved DFT Potential Energy Surfaces via Improved Densities. The Journal of Physical Chemistry Letters, 6(19), 3802-3807. https://doi.org/10.1021/acs.jpclett.5b01724

Pinter, B., Chankisjijev, A., Geerlings, P., Harvey, J. N., \& De Proft, F. (2018). Conceptual Insights into DFT Spin-State Energetics of Octahedral Transition-Metal Complexes through a Density Difference Analysis. Chemistry - A European Journal, 24(20), 5281-5292. https://doi.org/10.1002/chem.201704657

Rappe, A. K., Casewit, C. J., Colwell, K. S., Goddard, W. A., \& Skiff, W. M. (1992). UFF, a full periodic table force field for molecular mechanics and molecular dynamics simulations. Journal of the American Chemical Society, 114(25), 10024-10035. https://doi.org/10.1021/ja00051a040

Schmidt, M. W., Baldridge, K. K., Boatz, J. A., Elbert, S. T., Gordon, M. S., Jensen, J. H., .. Montgomery, J. A. (1993). General atomic and molecular electronic structure system. Journal of Computational Chemistry, 14(11), 1347-1363. https://doi.org/10.1002/jcc.540141112

Siegbahn, P. E. M. (2006). The performance of hybrid DFT for mechanisms involving transition metal complexes in enzymes. JBIC Journal of Biological Inorganic Chemistry, 11(6), 695-701. https://doi.org/10.1007/s00775-006-0137-2

Stevens, W. J., Krauss, M., Basch, H., \& Jasien, P. G. (1992). Relativistic compact effective potentials and efficient, shared-exponent basis sets for the third-, fourth-, and fifth-row atoms. Canadian Journal of Chemistry, 70(2), 612-630. https://doi.org/10.1139/v92-085

Witte, J., Neaton, J. B., \& Head-Gordon, M. (2017). Effective empirical corrections for basis set superposition error in the def2-SVPD basis: GCP and DFT-C. The Journal of Chemical Physics, 146(23), 234105. https://doi.org/10.1063/1.4986962

Yanai, T., Tew, D. P., \& Handy, N. C. (2004). A new hybrid exchange-correlation functional using the Coulomb-attenuating method (CAM-B3LYP). Chemical Physics Letters, 393(1-3), 51-57. https://doi.org/10.1016/j.cplett.2004.06.011

Zhang, Z., Yang, S., Dou, M., Liu, H., Gu, L., \& Wang, F. (2016). Systematic study of transition-metal (Fe, Co, Ni, Cu) phthalocyanines as electrocatalysts for oxygen reduction and their evaluation by DFT. RSC Advances, 6(71), 67049-67056. https://doi.org/10.1039/C6RA12426G 